\title{
Utilization of the Three-Dimensional Model to a Construction Production System
}

By Keizo Kanzaki

Abstract- The quitting a job of the expert worker and the lack of the technical transmission to the young worker with low birthrate, and the deterioration of the infrastructure institution which will increase rapidly in future will be the problem that must put up measures immediately in the construction business. CIM and i-Construction proposed by Ministry of Land, Infrastructure, Transport and Tourism enforce the improvement of the productivity of the construction site and the maintenance and check for the life cycle of the structure using three-dimensional model in order to solve such a problem, and they may be said that it is the big change of the construction production system. In this report, I survey three examples of the tool which I can utilize threedimensional model for plan, measuring, construction, and maintenance based on a policy of CIM and i-Construction, explain an effective making method of the three-dimensional model suitable for a construction scale and contents and examine the effective utilization method and introduction effect in the construction production system.

Keywords: CIM, information-oriented construction, laser scanner device, UAV.

GJRE-E Classification: FOR Code: 290804

Strictly as per the compliance and regulations of:

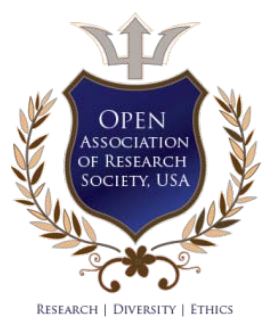

(c) 2020. Keizo Kanzaki. This is a research/review paper, distributed under the terms of the Creative Commons AttributionNoncommercial 3.0 Unported License http://creativecommons.org/licenses/by-nc/3.0/), permitting all non-commercial use, distribution, and reproduction in any medium, provided the original work is properly cited. 


\title{
Utilization of the Three-Dimensional Model to a Construction Production System
}

\author{
建設生産システムへの 3 次元モデルの活用 計画・施工・維持管理への活用事例
}

Keizo Kanzaki

\begin{abstract}
The quitting a job of the expert worker and the lack of the technical transmission to the young worker with low birthrate, and the deterioration of the infrastructure institution which will increase rapidly in future will be the problem that must put up measures immediately in the construction business. CIM and i-Construction proposed by Ministry of Land, Infrastructure, Transport and Tourism enforce the improvement of the productivity of the construction site and the maintenance and check for the life cycle of the structure using three-dimensional model in order to solve such a problem, and they may be said that it is the big change of the construction production system. In this report, I survey three examples of the tool which I can utilize three-dimensional model for plan, measuring, construction, and maintenance based on a policy of CIM and i-Construction, explain an effective making method of the three-dimensional model suitable for a construction scale and contents and examine the effective utilization method and introduction effect in the construction production system.
\end{abstract}

Keywords: CIM, information-oriented construction, laser scanner device, UAV.

\section{I。はじめに}

${ }^{1}$ $\mathrm{M}$ や i-Construction の導入により，現場におい て 3 次元 モデルを活用する事例が増えつつある 。CIM は，限られた公共投資の中で効率的な社 会資本整備を行うことや， ストック型社会への転換に 向けた社会資本のアセットマネジメントの導入，地球 環境に配慮した社会資本整備（アセスメント，LCA， リサイクル等）の実現などを目的としており，近年で は，単なるモデル化だけでなく，トータルマネジメン トや社会資本整備の全体最適化として捉えられてきて いる 1 ).

CIM は，建設構造物に各種の情報を付加した モデルを作成し，社会資本の整備や維持管理の効率化 を目指す取り組みであるが，CIM 実現のためには，業 務フロー，執行体制の見直しと，これを実現するため のデータ作成，可視化，データ蓄積技術の確立が不可 久となっている。特に構造物のモデル化については,

「形状の見える化」だけでなく，地形・地質のモデル 化も重要である。また，構造物のライフサイクルにわ たる維持管理・点検については，「履歴の見える化」 も重要な要素である。
現状での CIM の導入については，建設から維 持管理・構造物の廃棄まで一貫して活用する将来の理 想系をイメージしつつ，現時点の導入にあたっては「 できることから実施していく」考えで段階的に進めて いくことが現実 的な対応である 2 ).

\section{3 次元モデルの作成や活用に関する既往の研究}

近年の測量技術は，3 次元レーザスキャナ計測 に代表 される面的な点群データ計測技術の普及により , 従来使用されてきた点と線で地形や構造物を表現し ていた時代から，面で取得する方向へ，また，2 次元 から 3 次元でデータを取得する方向に移行してきてい る.

面で取得する手法は，広域な範囲を均一な成 果で, 安価に取得できるという利点がある一方，点と 線で取得する方法は, 電子基準点のみを使用した GNSS 測量も進められており，基本的にはごく限られ た範囲を密に高精度で取得するという特質がある。

現況地形や既存構造物の 3 次元点群データ計 測手法を，表-1に列挙する。事業規模や目的に見合う 精度を求めて，最適な作成手法を選択する。専用の 3 次元モデルで作成する構築する構造物の 3 次元モデル と，表-1 の手法で作成する現況地形や既存構造物の 3 次元モデルを合成する.

3 次元モデルの作成手法である 3 次元レーザス キャナや空撮測量 (UAV) の研究としては, 櫻井 3) らは，地上設置型レーザスキャナを用いて，傾斜面や 整地されていない地表面, 久損した地表面に対し, 土 工事の出来高管理

Author: Project Technology Department, Kumagaigumi Co, Ltd. e-mail:kkanzaki@ku.kumagaigumi.co.jp 
表 $1: 3$ 次元点群データ計測手法の比較

\begin{tabular}{|c|c|c|}
\hline 手法 & 3 次元レーザスキャナ & 空撮測量 \\
\hline \multirow{6}{*}{} & レーザ光線を発して, 物 & UAV (Unmanned Aerial \\
& 体に少しづつ角度をずら & Vehicle : 無人航空機) \\
& して面的に照射しながら & を用いて, デジタル \\
& 反射光を計測することに & カメラと写真測量技 \\
内容 & より, その範囲にある物 & 術のソフトウェアで 3 \\
& 体表面の点群データを作 & 次元点群データを作 \\
& 成 & 成 \\
\hline \multirow{6}{*}{ 性能 } & (1)固定式地上レ一ザ計測 & UAVの普及により, \\
& (精度:数mm程度) & 比較的容易に広範囲 \\
& (2)MMS & を短時間で測量する \\
& (精度 : $10 \mathrm{~cm}$ 程度) & ことが可能, 精度は \\
& (3)航空レ一ザ測量 & レーザスキャャナに比 \\
& (精度:数 $10 \mathrm{~cm}$ 程度) & ベて低い \\
\hline
\end{tabular}

出典：「CIM 入門一建設生産システムの変革一」矢吹信喜著

のための地表面の生成が可能であることを実証実験で 示した. また, 田中 4)らは, レーザスキャナ搭載 UAV による点群データの解析・処理技術の調查を行い, 今 後の利活用一向けた検証を行っている. 櫻井 5)らは, UAV による空中写真測量時に作業者が考慮す心゙き項目 を明らかにするために, 空中写真測量における誤差要 因の影響度や発生条件を調査し，各手法による点群デ ータから 3 次元モデルを作成するにあたっての課題の 抽出や実証結果を示している. 今村 6)らは, MMS ( Mobile Mapping System) を用いて道路施設（信号機 灯具や白線）を対象に 3 次元点群データを用いた抽出 方法について検証を行っている.

次に, 3 次元モデルの公共工事への適用に関す る研究としては, 城古 7)らは，3 次元情報技術に関す る活用事例をもとに，どのようなフェーズで，どのよ うな効果, 課題, 変革があるかを抽出し, 公共工事へ の適用を考察し，公共土木工事が目指寸べき方向性に ついて述べている。 また，宮武 8) 9) 10)らは，築堤事 業の施工段階に CIM を適用した試行工事に関し, 協議 資料から設計照査，施工計画，測量，施工·設計変更 ，検査までの各段階において，３次元モデルを活用し た結果について記述し, 導入する場合の第三者の位置 づけや役割, 運用上の課題について述べている. 藤田 11) らは，河川事業において CIM を導入し，河川の 3 次元モデルによる不可視部分の可視化や経年変化の可 視化, 縦横断変化の可視化や過去の遍歴の投影が可能 でありことを示し，これらが維持管理を行う上で有用 であると述べている。

構造物に関しては, 藤澤 12) らは, 鉄道高架 橋を対象として 3 次元モデルを作成して数量算出を行 い, 2 次元図面 から作成した数量の比較や, 積算への 適用を検証している. 小林 13) らは, 鋼上部工を対象 に，作成する部材が非
常に多い構造物の 3 次元モデルを効率的に構築する手 法を提案し, 2 次元設計に対して業務効率化一寄与す る効 果を検証している. 田中 14), 清水 15), 山岡 16) らは橋梁の維持管理段階で効率的かつ利用しやす い3 次元モデルの作成方法を提案している.

ダムやトンネル工事にあたっては，施工箇所 の地質状 況を詳細に把握し, その状況に応じて最適な 設計および 施工を実施することが重要であり, 宇津木 17) らは, 地質の情報を 3 次元化する CIM 対応ソフト を開発し, 施工に 活用し, 維持管理に必要な属性情報 を選定している。また，杉浦 18)らは，施工 CIM とし て切羽情報や覆工情報を 3 次元モデルに取込み, 一元 管理を行い, 維持管理 $\mathrm{CIM}$ への展開について検証し ている. 畑 19)らは, 山岳トンネルにおいて, 切羽前 方地質情報を CIM に連携して, 予測型 CIM を開発し トンネル周辺の地質情報を明確化し，地 質構造モデ ルを作成することで施工後の維持管理情報として活用 している.

これらの先行研究は, 3 次元モデルの作成手法 を精度や効率化の面から検証し，3 次元モデルを公共 工事の各施工段階で運用した結果や, 維持管理情報と しての利活用の現状把握や今後の可能性について記述 されており，非常に有益なものである．ただ， 3 次元 モデルの作成手法を選択した経緯について言及したも のは少ない. CIM や i-Construction の概念は, 計画・ 調査から検査, 維持管 理まで 3 次元モデルを主体とし て実施することであるが, 事業内容, 規模, 工種によ り最適な 3 次元モデルの作成手法があり, かつどの建 設生産プロセスにおいて 3 次元モデルが有効に活用で きるかは事業内容, 工種によって異なることが考えら れる。

本稿は, 工種の異なる 3 事例を紹介し, 計画 段階から 測量, 施工管理, 維持管理に至る建設生産プ ロセスに着目し，3 次元モデルの作成手法を選択した 
経緯，および 建設生産プロセスにおける有効な活用方 法，その導入効果について検証する.

\section{III.＼cjkstart建設生産システムへの適用事例}

本章では，建設生産システムを(1)計画，(2)測 量・施工，(3)維持管理への利用に分類した上で，3 次元 モデルを活 用している 3 事業（橋梁下部工工事，大規 模土工事，山岳トンネル工事）について報告する.

a) 計画段階への適用事例 〜橋脚下部工工事〜

\section{i. 事業内容及び 3 次元モデル作成手法}

筆者らは，中部地方整備局発注の高速道路で 橋脚下部 工を 3 基（1 基はフーチングのみ）施工する 工事を, CIM 試行工事として取組んでいる。写真-1 に 示寸工事箇所の中央分離带付近に橋脚を構築する. 計 画段階で構築する 構造物と既存の防音壁や地下構造物 との離隔を把握することが施工前に要求されたため, 3 次元にモデル化することが視覚的に効果的であると 考えた. 3 次元モデル作 成手法として, 現況測量する にあたり，施工箇所が幹線 道路であるため，UAV 測量 を行うには許可を申請する 必要がある。また，道路周 囲の防音壁や中央分離帯の突 起部などを高い精度でモ デル化する必要があったため, 固定式 3 次元レーザス キャナ（GLS-2000：TOPCON 製） で測量を実施する こととした。測量期間は，測量範囲（縦断 $150 \mathrm{~m}$ ，横 断 40m) において，3 日間（機器据付け 回数約 30 回 ）の日数を要した.3 次元点群データ（図-1）取得後 3 次元モデルを作成し，さらに 2 次元図面から専用 の 3 次元ソフトで作成した 3 次元の構造物モデルや 地 層データを合成した（図-2.

次に，鉄筋の組立工に関しては，鉄筋梁部は 過密鉄筋 で，PC 鋼材も配置することから鉄筋と PC 鋼材が輻輳することが想定された。このため，事前に 2 次元図面から 鉄筋の 3 次元モデル化を行い, 組立て る上で支障となる 箇所を把握することとした（図-3, 図-4）.

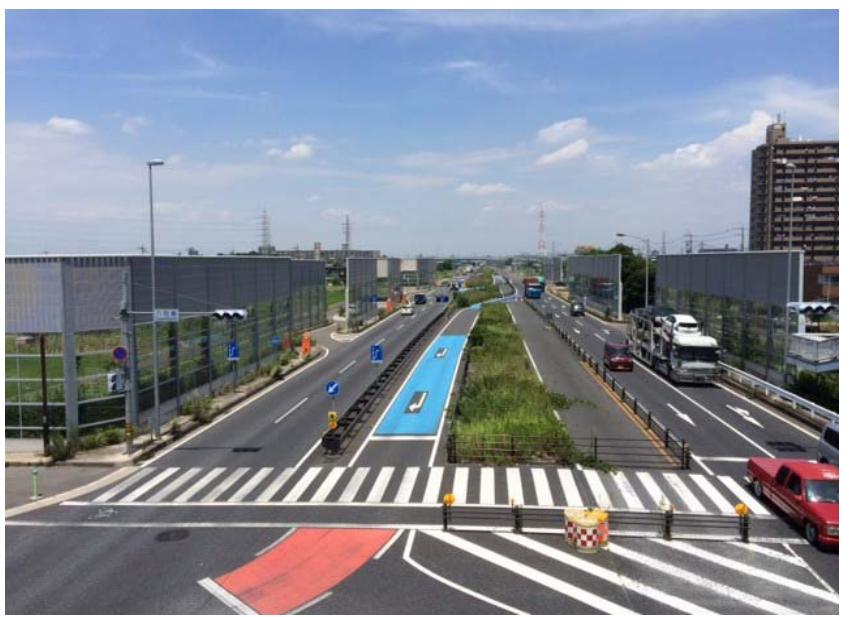

写真-1 工事箇所施工前状況

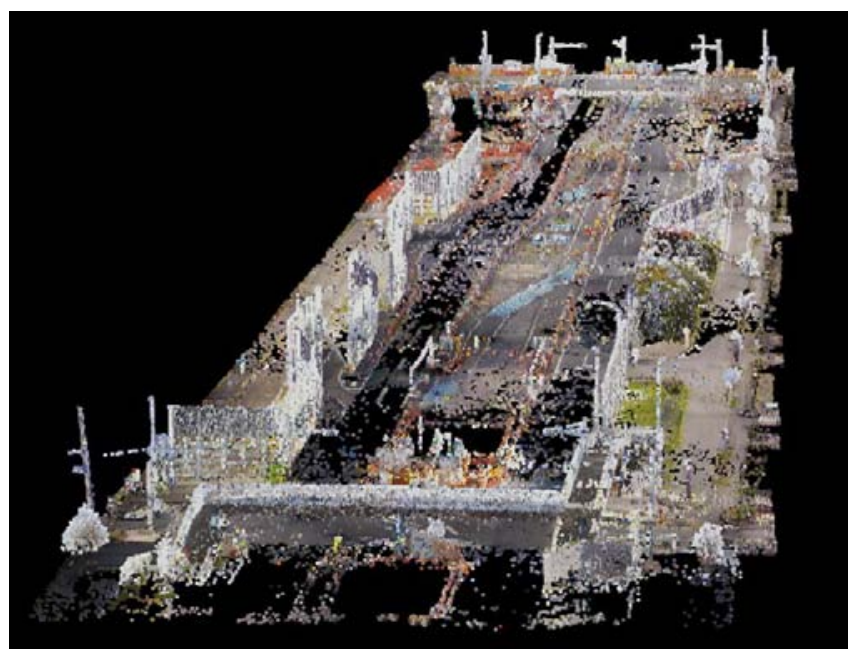

図-13 次元点群データ

ii. 導入による効果

計画段階で 3 次元レーザスキャナによる測量 を実施し, 現況地形と既存構造物の 3 次元モデルの作 成と, 構築する橋脚の 3 次元モデルを合成すること, 既存構造物と橋脚の位置関係が正確に把握でき，防音 壁との離隔が施 工に支障とならないか 3 次元的に確認 寸ることが可能となった. 鉄筋についても，3 次元化 することにより，パーツ毎の 2 次元図面では把握でき なかった鉄筋の干渉部を簡単に抽出することが可能と なった。また，事前に鉄筋輻輳部の組立て完了後の 3 次元モデルを見ることで，鉄筋組立て手順のイメージ をたて易くなり，組立て前に，組立て手順を職員と鉄 筋工で確認でき, 施工時に組立て不可能になるなどの 手戻りを防止することができた。

以上より，本工事では計画段階におけるレー ザスキャナによる 3 次元モデル化が「形状の見える化

に効果を 発揮し、施工にあたって非常に役立ったと いえる。

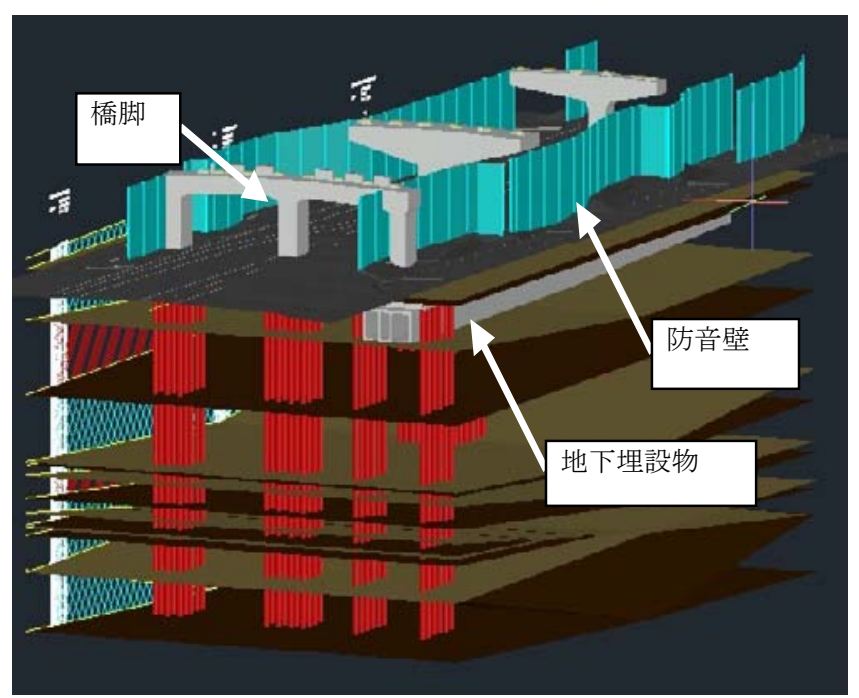

図-2３次元モデル 


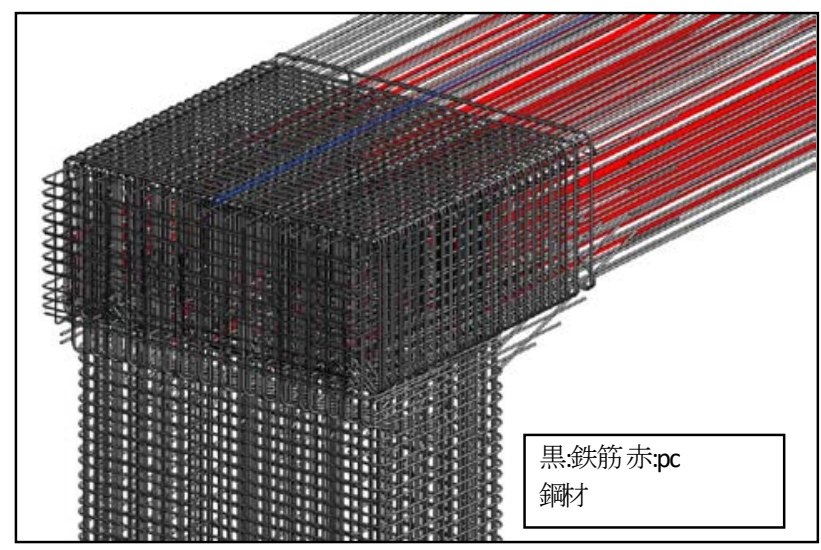

図-3 鉄筋・pc 鋼材の 3 次元化

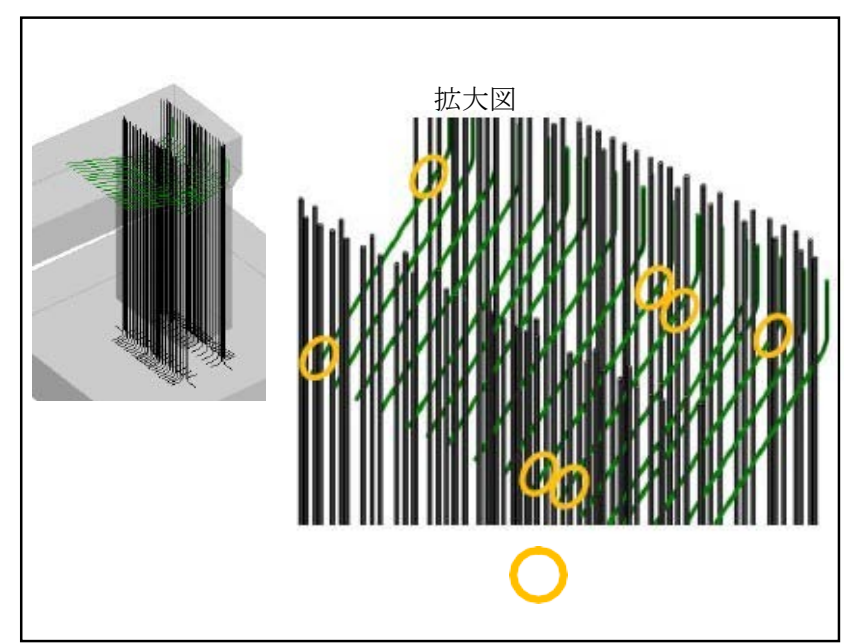

図-4 干渉鉄筋部

b) 測量 - 施工段階一の適用事例 〜大規模土工事〜

i. 事業内容及び 3 次元モデル作成手法

静岡県発注の工業団地の造成工事で，施工面 積約 31ha, 切土量約 76 万 m3, 盛土量約 63 万 m3 大規模土工事である。本工事では，i-Construction を見 据えて施工当初から 3 次元 モデルを作成し, 測量や施 工段階で情報化施工の運用や 進渉管理を実施している (図-5).

3 次元モデル作成手法として, 広大な施工面積 の測量 を短期間で行う必要があること, 数十万 m3 の 土量算出のため, 精度は数 $\mathrm{cm}$ 単位で良いこと, など の理由から UAV を使用した（写真-2, 表-2）。UAVに 搭載したデジタルカメラで航空写真を撮影し，専用の ソフトで点群データを作成した（写真-3, 図-6）。 UAVによる測量方法は，現況測量として，施工範囲を 伐採が完了した箇所から 3 回に分けて順次実施した。 さらに, 設計図面より最 終仕上がり形状をを 3 次元モ デル化し（図-7），UAV 測 量による 3 次元地形データ と比較して施工段階での土量 等高線分布図を作成した

（図-8）。切土・盛土量を算出できるとともに，運土 計画を立てることができた。
さらに，施工時の進渉管理を目的として，土 工事の竣 工（平成 29 年 12 月）に合わせて 2 回(進渉 40\% 時点と進渉 70\% 時点), UAV 測量を実施し, 土工 量を把握した。

施工は, UAV 測量で得られた現況地形の 3 次 元データと 2 次元設計図書から作成した最終仕上がり 形状の 3 次元 設計データを利用する.

盛土材の敷均し作業は，ブルドーザに高精度 の GNSS 受信機を設置し，これらの3 次元データをブ ルドーザに取込むことで, 機体位置の標高と設計高さ をリアルタイムに照合できる. 予め取込んだ 3 次元デ ータをリアルタイムに照合して，機体位置の標高と設 計高さを把握する。 自動制御機能により排土板を施工 箇所位置の設計撒き出し高さに自動で上下させ，撒き 出し，および敷均しを行う。オペレータは，運転席の モニターで設計值と排土板の高さを確認しながら前後 進を繰り返す．排土板は指定通りの高さまで自動で可 動する（写真-4，写真-5）

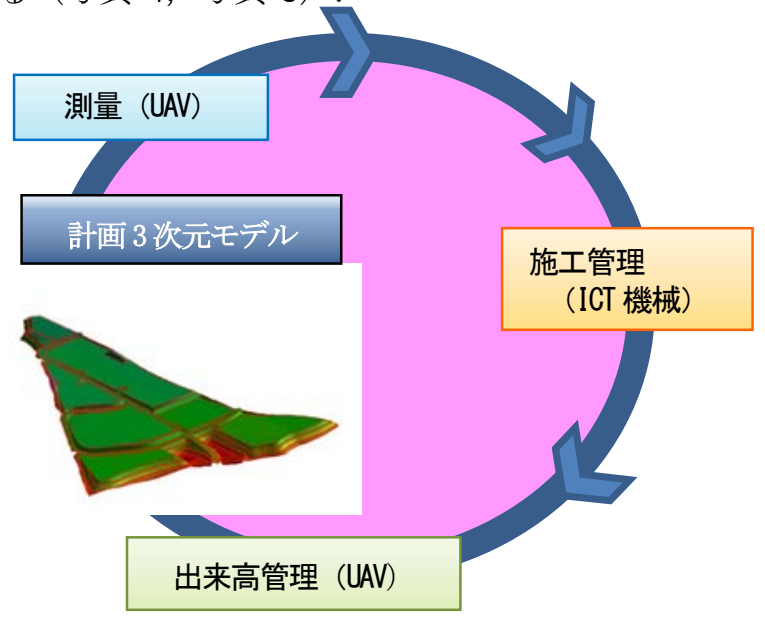

図-5 取組夕概念図

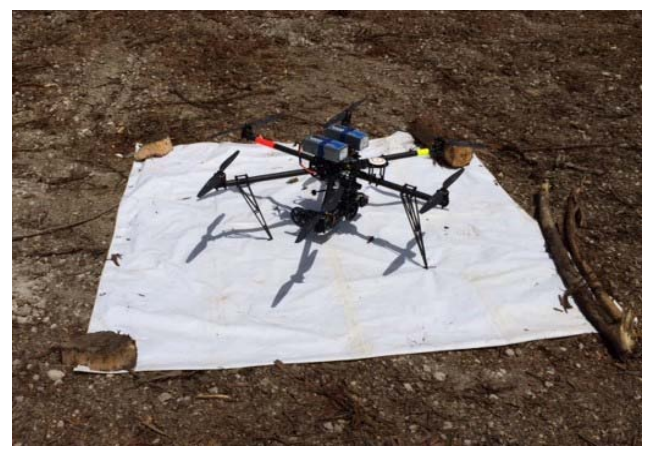

写真-2 UAV（SPIDER CS6）

表-2 UAV 仕様（SPIDER CS6）

\begin{tabular}{|c|c|}
\hline 項 目 & 仕 様 \\
\hline 機体重量 & $3,800 \mathrm{~g}$ \\
\hline 外形寸法 & $1,000 \times 1,000 \times 400 \mathrm{~mm}$ \\
\hline 躯 動 & モータ躯動 \\
\hline 耐 風 & $15 \mathrm{~m} / \mathrm{s}$ 以下 \\
\hline 飛行時間 & 10 分 $\sim 25$ 分 \\
\hline 撮影範囲 & 約 $1,000 \mathrm{~m}$ \\
\hline 到達高度 & $250 \mathrm{~m}$ \\
\hline
\end{tabular}




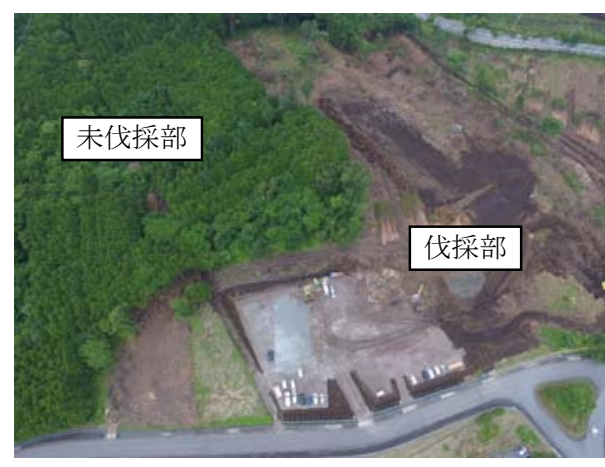

写真-3 航空写真

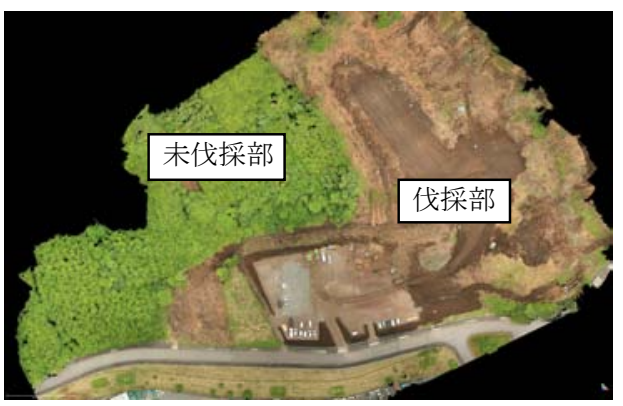

困-6 点群データ

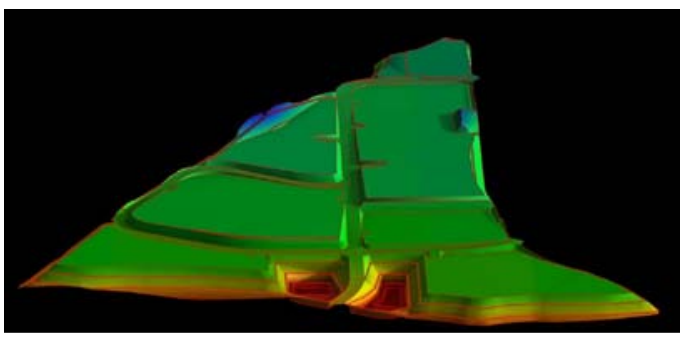

図-7 最終仕上がり形状（3次元モデル）

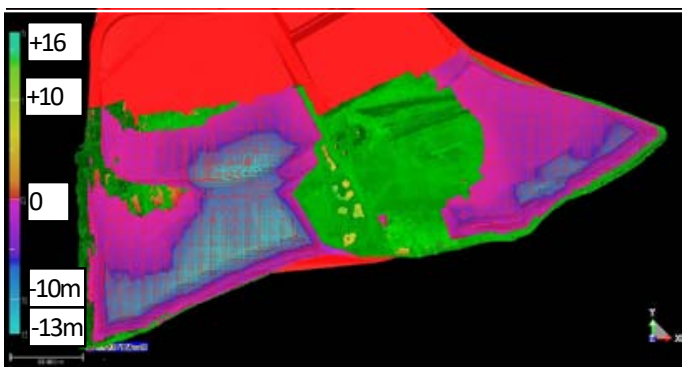

図-8 土工等高線分布図

さらに，ブルドーザに無線機（携帯データ通 信：Wi- Fi）を搭載し，サーバーとのネットワークを 構築することで情報の送受信を可能にして重機の位置 情報を把握できるシステム（システム名:VisionLink） を導入した。本システムにより，パソコン上で日々の 重機や出来形の情 報をリアルタイムに確認でき，施工 管理の「見える化」に役立っている.

モニター画面の一例を示す。ブルドーザが作 業している位置の標高を色分けで表示する．画面上で 任意の断面を設定して表示でき，計画に対して現在ど
のあたりで作業を行っているか進渉状況を把握できる （図-9）。また，ブルドーザが作業した範囲におけ る概算の土量を計算し，切土量・盛土量の算出を行う (図-10）.

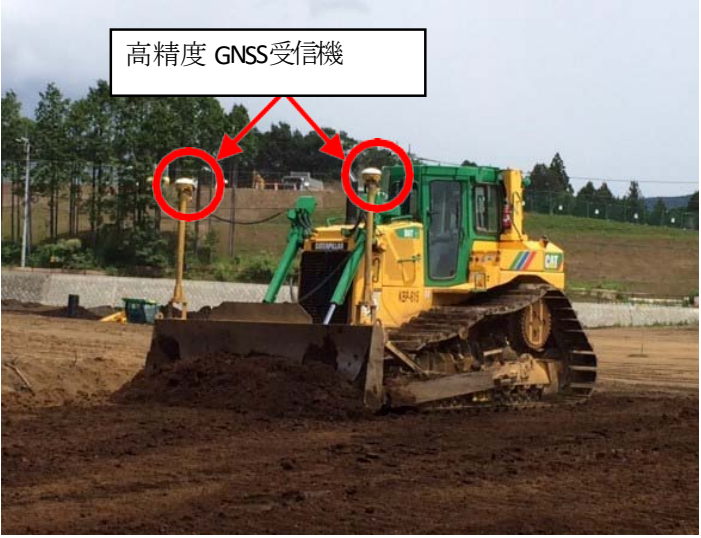

写真-4 排土板制御システム搭載ブルドーザ

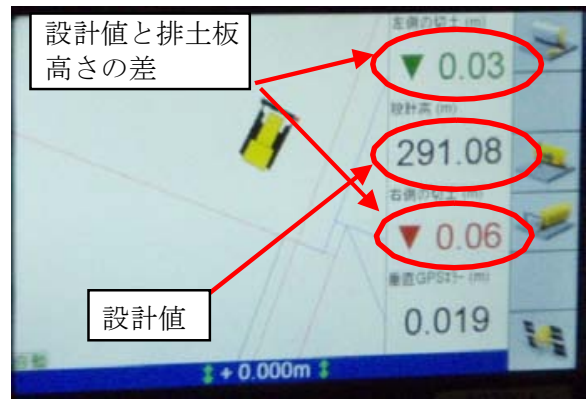

写真-5 モニター画面

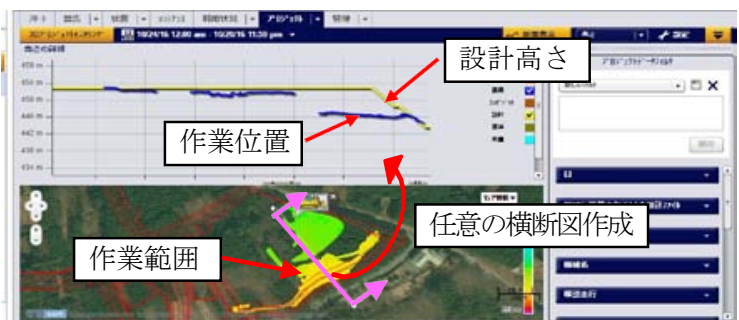

网-9ブルドーザが作業している標高表示

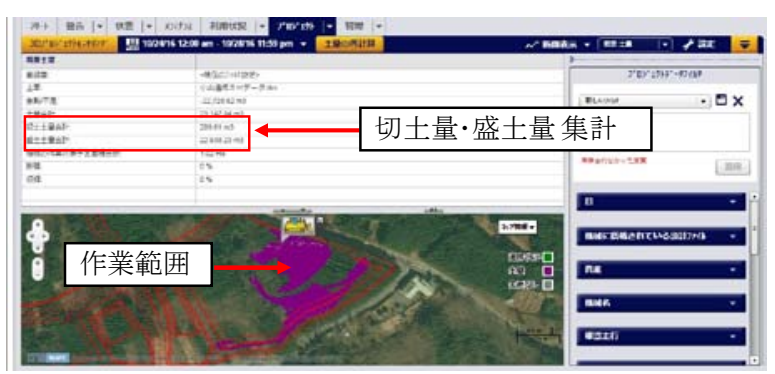

困-10 概算切盛土量表示

敷均し後の締固め作業は，振動ローラを使用 する。機 体の屋根に設置した GNSS 受信機で位置を 把握し, 締固め面の施工情報（締固め範囲, 高さ）に 加え, 締固め位 置, 締固め回数を運転席のモニター画 面にリアルタイムに表示する. 
オペレータは機体を操作しながらモニター上 のメッシュ $(50 \mathrm{~m} \times 50 \mathrm{~m})$ の色が転圧する毎に変わっ ていくのを確認し, 所定の回数（試験施工で決定した 必要な回数）の色になるのを確認して終了とする（写 真-6, 写真-7) .

法面掘削作業は，バックホウを使用する。機 体には高 精度の GNSS 受信機を設置し, アーム部に 取付けたチルトセンサーより, バックホウとバケット の位置を測定す るガイダンス機能により作業を行う。 オペレータのモニ ター画面には, 最終形状の 3 次元設 計データから得られる施工箇所の設計切土ラインとバ ケットの位置が表示される. オペレータはバケットの 位置と設計ラインまでの 距離をモニターで確認しなが ら作業することができる（写真-8，写真-9）。

さらに，最終仕上げ時はマシンコントロール 機能を使用して法面整形を実施している。 バケット角 度保持モード機能を搭載しているため, バケットの角 度が固定され，オペレータは上下に操作するだけで, 設計切土ラインに整形できるという仕組みになってい る(図-11.

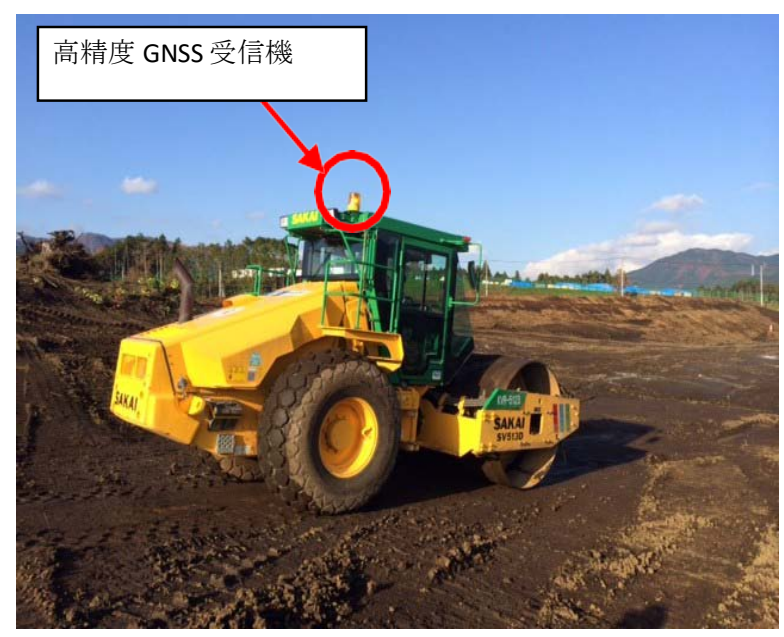

写真-6 転圧管理システム搭載振動ローラ

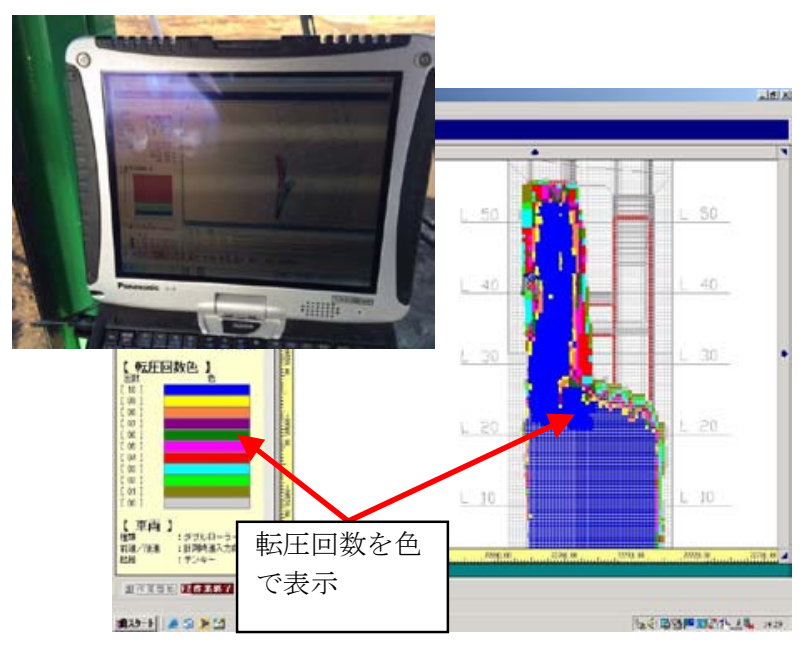

写真-7 モニター画面

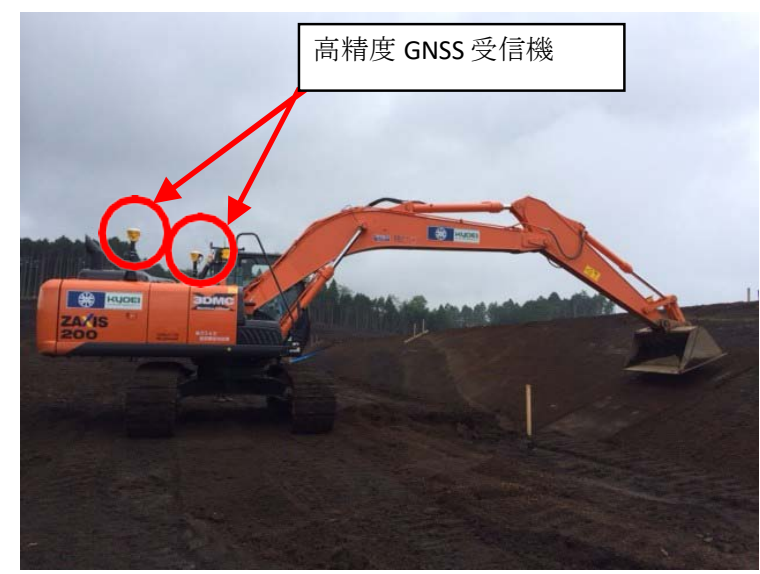

写真-8 マシンガイダンスバックホウ

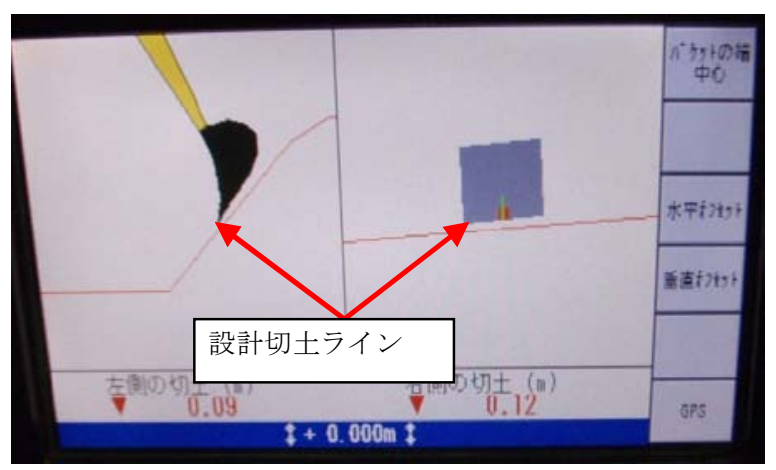

写真-9 モニター画面

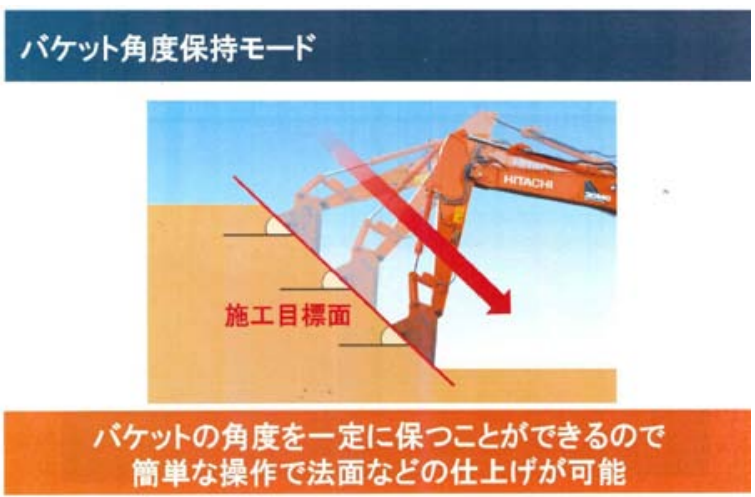

出典 : HITACHI カタログ

「ICT 油圧ショベル ZAXIS200」

図-11 マシンコントロール機能概念図

c) 導入による効果

測量に関しては，UAV を使用することにより 航空写真から点群データ, 3 次元モデル作成に費や 寸時間は約 1〜2 週間である. 本工事のような大規模 な施工面積の 場合, 従来は測量だけで 2 週間以上かか るため, 測量から 3 次元モデル作成に費や寸時間を大 幅に削減することが可能となった。 また, 施工段階に おいては, 切土量, 盛土量が自動算出できるため, 設 計数量との対比や運土 計画, 出来高管理を効率的に行 うことができた. 
GNSS を用いた ICT 機械の導入により，基本 的に測 量杭は不用となるため, 丁張り設置や検測作業 がなくなり測量作業の省力化を図ることができた。ま た，施工時 も丁張りを目安にした点や線の管理に代わ り，モニタ画 面で施工範囲全面の面的な管理を行え， 仕上がり精度の 向上や締固め回数の正確な管理を行う ことが可能となった。熟練でない経験の浅いオペレー タが作業しても，熟 練労働者と同等の仕上がりを行う ことが可能となる。

締固め作業における施工情報は，自動で保存 され，盛土の品質データとして自動保存できる. 以上より，このような施工面積の広い造成工事では， 測量で UAV を，施工管理で ICT 機械を使用することで 施工の効率化，省人化，品質の向上に非常に役立つ といえる。

\section{IV. 維持管理への利用事例 〜山岳トンネル工事〜}

a) 実施内容及び 3 次元モデル作成手法

近畿地方整備局発注の山岳トンネル（延長 1,295m） 工事である。工事完了後の維持管理段階へ の利用を主目 的とするため, 表-1による作成手法は選 択せず，専用ソフトで CIM 用 3 次元モデルを作成し た．作業は，3 次元モ デルに施工データ（品質・出来 形）を入力することに重 点をおき，かつ地質脆弱部の 地質モデルも 3 次元化し，これらを維持管理データと して竣工時に発注者へ引渡しを行った。

掘削時は, 切羽写真を 3 次元モデルに連続的 に並べ切羽観察情報を入力した（図-12），覆工も 3 次 元モデル化し，コンクリート品質データや出来形情報 を入力し, 覆 エブロックをクリックするとクリックし たブロックの属 性情報が全て見れるようになっている

\section{(図-13)}

3 次元地質モデル作成手法として, (1)地質縦 断図，(2) 地質平面図，(3)トンネル線形図，(4)標準断面 図，(5)先進 調査ボーリング（2 箇所），(6)切羽写真を 参考資料として，専用の 3 次元地質モデルソフトを用 いて，大局的な地質モデルを作成した。本トンネルは 古第三紀の凝灰 角砅岩(Ytb)が全域にわたり分布し， その上に古第三紀の砂岩(Yss), 段丘堆積物(tr), 崖錐 堆積物 (dt)が累重する。これらの地層のモデリングを 実施した（図-14,図-15）。

先進調査ボーリング結果では，地質脆弱部， 破砕带部 ともボーリング間のほぼ全体に角礫状・砂礫 混じり粘土 状が分布しており, 切羽写真データでも亀 裂が発達していることが確認できた。これらと，地質 縦断図や地表面 形状加ら，地質脆弱部，破砕帯部の境 界面を想定したのち地質モデルを推定した，走向方向 は，地形データから 低土被りとなっている沢筋を通る ように分布させた（図-16,図-17）。

さらに，脆弱部（Ytb 層風化部）と破砕帯部を 全体の 3 次元モデルにはめ込んだものを図-18 に示す このモデルから縦断切断面を作成することにより，
将来，計画 されているI期線トンネル部の地質状況を 推定すること ができ， II 期線施工の掘削時に役立てる ことができる（図-19）。

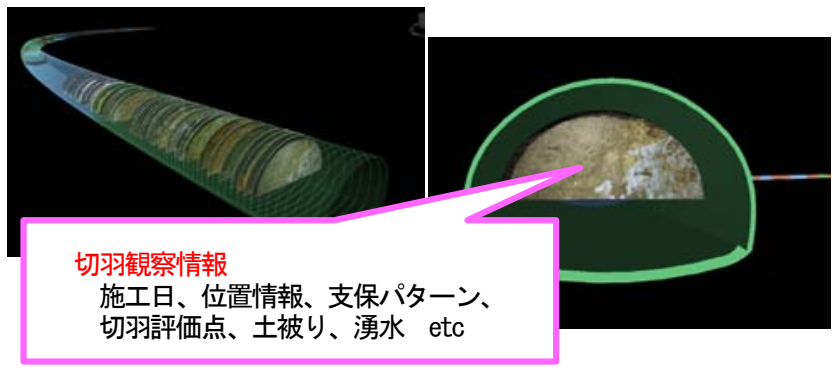

図-12 切羽モデル図

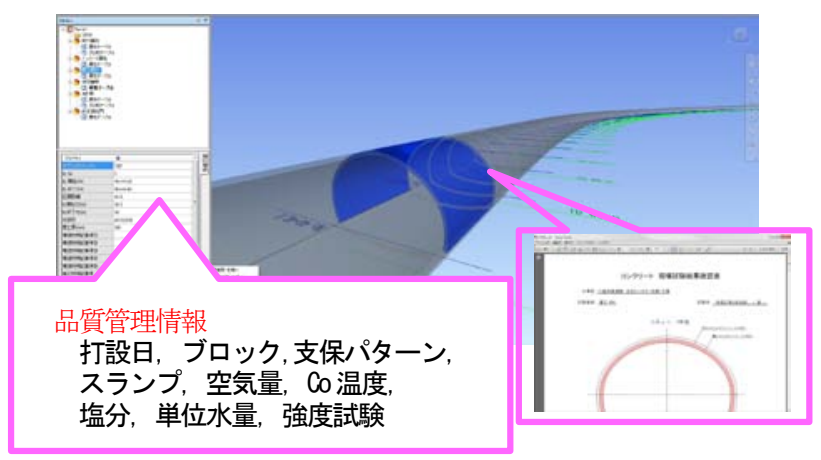

図-13 覆工モデル図

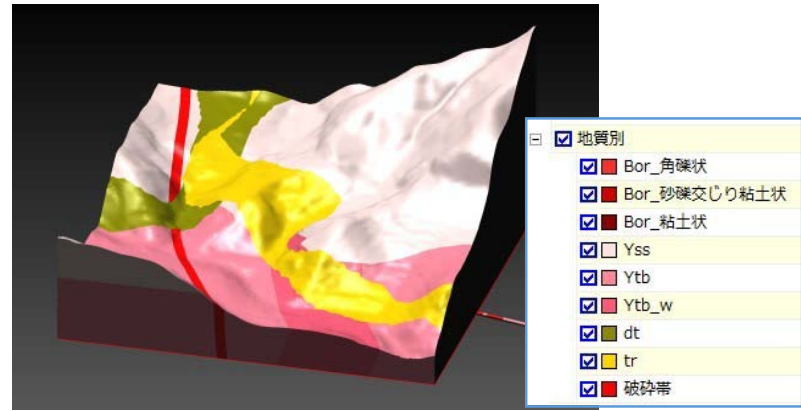

図-14 地質モデル全体図

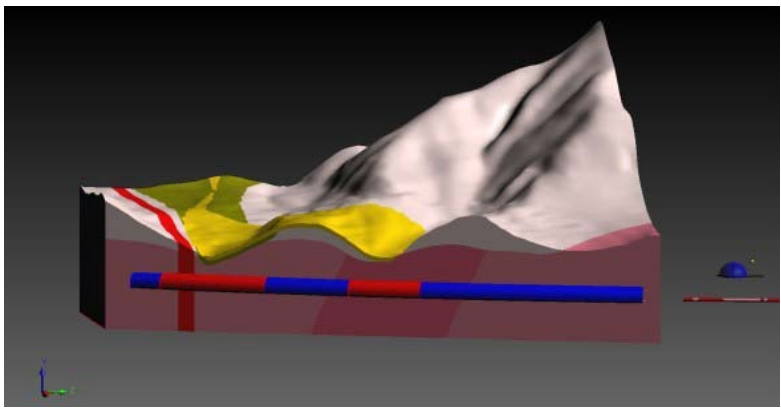

図-15 地質モデル切断図 


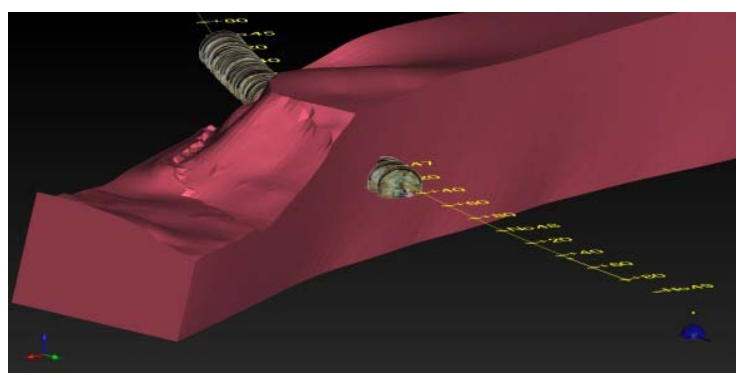

図-16 脆弱部 3 次元モデル化

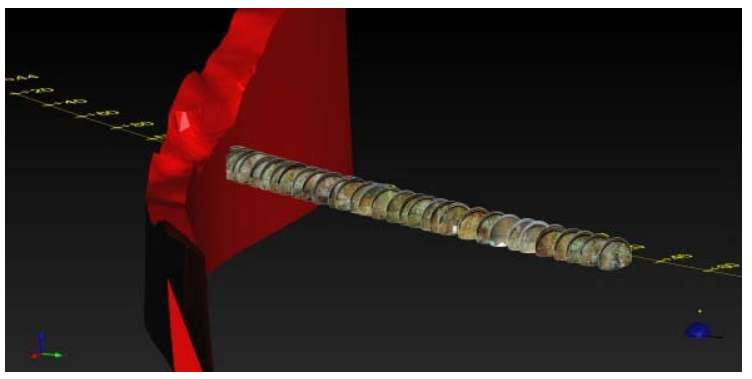

図-17 破砕帯 3 次元モデル化

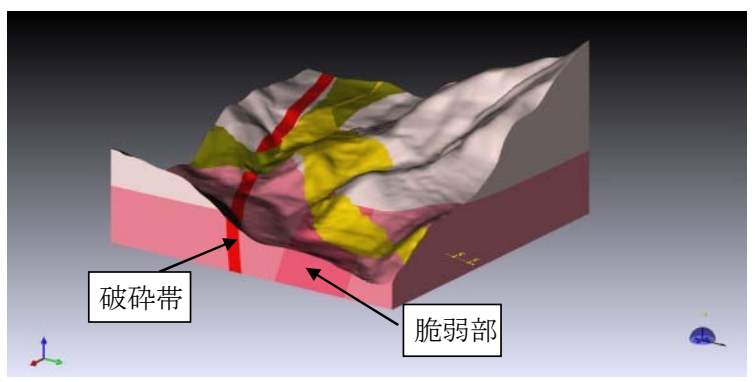

図-18 全体地質モデル化（脆弱部・破砕帯）

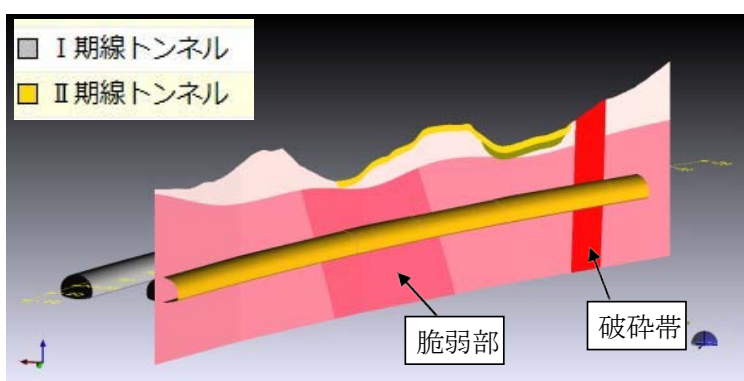

図-19 II期線トンネル CL での縦断切断図

b) 導入による効果

今回，維持管理業務への利活用ということで トンネル施工時のデータを 3 次元モデルに取り込む ことを主業 務とし，さらに，各種地質データを基に地 質モデルを 3 次元化し，地質脆弱部や破砕帯区間の可 視化を可能とした。これらのデータをしゅん工時に発 注者に引き渡し, 将来, 維持管理・点検時にこの 3 次 元モデルに点検結果を順次保存していくことで，「履 歴の見える化」を行うことが可能となった.

また， 3 次元トンネル CIM データ（掘削時の 情報，計測データなど）に地質モデルを重ね合わせた ことで，トンネル施工情報と地質情報（地質脆弱部や
破砕帯区間） が関連付くとともに， II 期線施工時の非 常に有効なデータとして利用することが可能となる.

$$
\text { V。おおりに }
$$

工種の異なる 3 事業に対し, 施工規模や施工 内容に適した 3 次元モデルの作成手法, 建設生産プロ セスにおける活用方法や導入効果について検討を行っ た

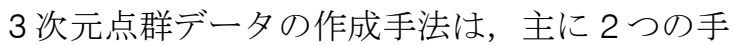
法がある が，施工範囲が大きくなく，既存の道路施設 構造物など 高い精度を要求される 3 次元モデルの作成 には，3 次元レーザスキャナを使用することで，施工 前に既存構造物々 構築構造物の位置関係を詳細に把握 でき，計画段階での 形状の見える化」に効果を発揮し た.

一方，施工面積が広い造成工事において，施 工前の土 工量把握や施工段階での進渉管理を行うには ，UAVを使用することで, 従来の方法より短時間で土 工量を算出できた. さらに, 3 次元データを基にした ICT 機械の稼働 により, 施工の効率化と品質向上に効 果を発揮した。

山岳トンネル工事においては，トンネル線形 の 3 次元 モデルに切羽情報や覆工データを属性情報と して入力することで，「履歴の見える化」が可能とな り，今後の維 持管理業務に活用できる. さらに脆弱化 した地質部の 3 次元データを重㸚合わせることで, 次期工事の施工情報 として有益なものになると考えら れる。

謝辞 : CIM や i-Construction の導入にあたり ご指導を賜った各発注者の皆様にこの場を借りてお 礼を申し上げます。

\section{参考文献}

1. 佐藤直良, 矢吹信喜 : CIM の歴史と可能性, 土木 学会誌 Vol.100 No.6, pp.10-13, 2015

2. (一財) 日本建設情報総合センター：CIM 技術検 討会平成 25 年度報告書, pp.12-65，2013.

3. 櫻井淳, 田中成典, 中村健二, 窪田諭, 中原匡哉, 平謙二：レーザスキャナを用いた施工現場の常時 観測における地表面生成技術の開発，土木学会論 文集 F3（土木情報学）,Vol.72,No.2, I _219-I 230,2016

4. 田中成典, 窪田諭, 今井龍一, 中村健二, 山本雄 平, 寺口敏生, 櫻井淳 : レーザスキャナ搭載 UAV 開発のための点群データ計測の利用場面と解析・ 処理技術 に関寸る調查研究，土木学会論文集 F3 （土木情報学）,Vol.72,No.2, II 82-II 89,2016

5. 櫻井淳, 田中成典, 中村健二, 窪田諭, 今井龍一

重高浩一：UAV の空中写真測量による施工管理 のための計測手法の提案, 土木学会論文集 F3（土 木情報学），Vol.72,No.2, II_73-II_81,2016 
6. 今村一紀, 佐田達典, 江守央 : MMS による 3 次元 点群データを用いた道路構造物抽出に関する研究 ，土木学会論文集 F3 (土木情報学) ,Vol.71,No.2, I 106- I 113,2015

7. 城古雅典, 森脇明夫, 有賀貴志, 石川和弘, 福士 直子：公共土木工事への 3 次元情報技術の適用に 対する提案, 土木学会論文集 F4 ( 建設マネジメ ント），Vol.72, No.4, I_135- I_144,2016.

8. 宮武一郎, 田村利晶, 盛伸行, 岡井春樹, 高岸智 紘：CIM を適用した築堤事業の施工段階における 3 次元モデルの作成・修正の支援に関する一考察 , 土木学会論文集 F4（建設マネジメント） ,Vol.72,No.4, I 145- I 154,2016

9. 宮武一郎, 岡崎仁司, 塚原大輔, 栗山卓也, 松田 寬志 : 3 次元モデルを利活用する堤防設計に関す る一考察, 土木学会論文集 F3 (土木情報学) ,Vol.72,No.2, I_42- I 51,2016

10. 宮武一郎, 田村利晶, 盛伸行, 岡井春樹, 高岸智 紘 : 築堤事業の施工における CIM の適用について の一考察, 土木学会論文集 F3 (土木情報学) ,Vol.71,No.2, II 18- II 27,2015

11. 藤田陽一, 星野裕司, 小林一郎, 水野純生 : 複数 の 既存データを併用した河川管理 CIM モデルの一 考察, 土木学会論文集 F3 (土木情報学) ,Vol.71,No.2, I_79-I_86,2015

12. 藤澤泰雄, 矢吹信喜, 五十嵐善一, 吉野博之 : 鉄 道高架橋を対象とした三次元設計モデルの積算・ 施工への利用, 土木学会論文集 F3（土木情報学） ,Vol.67, No.2, I_8- I_17,2011

13. 小林優一, 吉野博之, 谷口和昭, 金光都, 徳武広 太郎：CIM の概念を用いた鋼上部工の 3 次元モデ ルの構築に関する効率化の一提案, 土木学会論文 集 F3 (土木情報学)，Vol.72,No.2, II_90- II 95,2016

14. 田中成典, 北川悦司, 姜文渊, 安彦智史, 川野浩 平：道路橋上部工の維持管理のための 3 次元現況 図の自動生成に関する研究, 土木学会論文集 F3（ 土木情報学），Vol.68,No.2, I_181- I 189,2012

15. 清水智弘, 吉川眞, 瀧浪秀元, 御崎哲一, 高橋康 将, 中山忠雅, 内田修, 近藤健一：3D モデルを 用いた橋梁維持管理システムの開発，土木学会論 文集 F3 (土木情報学)，Vol.69,No.2, I _45- I 53,2013

16. 山岡大亮, 青山憲明, 谷口寿俊, 藤田玲, 重高浩 一：維持管理での利用を想定した橋梁の 3 次元デ 一タモデル標準の策定, 土木学会論文集 F3（土木 情報学)，Vol.71,No.2, I 204- I 211,2015

17. 宇津木慎司, 中谷匡志, 佐々木照夫：地質情報 CIM 管理システムの構築および施工現場への適用 , 土木学会論文集 F3 (土木情報学) ,Vol.72,No.1,24-31,2016.
18. 杉浦伸哉, 後藤直美: 紀勢線見草トンネル工事に おける施工 CIM から維持管理 CIM への取組み, 土 木学会論文集 F4（建設マネジメント） ,Vol.71,No.4, I_227- I_233,2015

19. 畑浩二, 杉浦伸哉, 後藤直美, 藤岡大輔 : 山岳卜 ンネルにおけるICT を活用した予測型 CIM の開発 , 土木学会論文集 F3 (土木情報学) , Vol.71, No.2, II_78- II_85,2015. 